\title{
Concept Paper \\ Additive Manufacturing in the Clothing Industry: Towards Sustainable New Business Models
}

\author{
Siavash H. Khajavi
}

Citation: Khajavi, S.H. Additive Manufacturing in the Clothing Industry: Towards Sustainable New Business Models. Appl. Sci. 2021, 11, 8994. https://doi.org/10.3390/ app11198994

Academic Editor: Marco Mandolin

Received: 19 August 2021

Accepted: 22 September 2021

Published: 27 September 2021

Publisher's Note: MDPI stays neutral with regard to jurisdictional claims in published maps and institutional affiliations.

Copyright: (C) 2021 by the author. Licensee MDPI, Basel, Switzerland. This article is an open access article distributed under the terms and conditions of the Creative Commons Attribution (CC BY) license (https:// creativecommons.org/licenses/by/ $4.0 /)$.
Department of Industrial Engineering and Management, Aalto University, 00076 Espoo, Finland; siavash.khajavi@aalto.fi

\begin{abstract}
The clothing industry is among the most polluting and waste-generating industries in the world, and it is responsible for the release of large amounts of greenhouse gases. The industry's massive size and significant environmental footprint with regard to water and energy consumption and waste generation make it a valid improvement candidate. While in recent years, global clothing brands and retailers have taken steps to reduce their ecological footprint, there still is a lot of room for improvement. In this research, we view this sustainability issue from a lifecycle perspective and study the new business models (NBMs) that may arise from the utilization of additive manufacturing (AM) technology. AM is emerging as a method of production for final parts. Moreover, as the range of material and available production processes expands, it is increasingly important to study the potential impact of this promising production technology and potential NBMs enabled by it on the clothing industry. Additionally, the obstacles to AM utilization in the clothing industry are explored. We utilize secondary data related to relevant implementation cases to theoretically study the NBMs that AM can enable to improve sustainability. Three NBMs of "clothing as a service", "collaborative consumption", and "direct sale/distribution" were envisioned through the study of current AM applications in other industries, as well as current fashion trends. The results of this research have implications for the sustainability of the fashion industry while also providing directions for AM technology development.
\end{abstract}

Keywords: 3D printing; additive manufacturing; clothing industry; new business models; sustainability

\section{Introduction}

The clothing industry is estimated to be worth about $2.2 \%$ of the world's gross domestic product (GDP) or about USD 1.68 trillion in 2015. Estimations also predict the continuation of growth in this industry [1,2]. The clothing industry makes up about $6 \%$ of global trade [3]. The enormous size of the industry makes attention to waste reduction an essential task. In the United States alone, landfills receive approximately 11 million tons of textile waste every year [4].

In addition to creating large amounts of waste, the clothing industry is highly waterand energy-intensive, and can pollute the environment. The source of clothing fiber is either natural (cotton, silk, sheep, etc.) or synthetic (such as oil-based polyester), and in both cases requires significant amounts of water and energy to be produced firsthand. While synthetic-based fibers release emissions of various types (such as acid gases and volatile organic compounds), cotton requires the use of pesticides that are harmful to the environment as well as humans [5].

Nowadays, clothes are considered to be disposable products, and the inception of fastfashion concepts increases the environmental risks if the product lifecycle is not carefully managed [6]. The use of clothing in a fast-fashion setting and with short lifecycles will increasingly put pressure on the world's environment and resources while making garment production an unsustainable industry. Therefore, it is essential to explore the possible 
methods of clothing lifecycle extension to reduce the industry's footprint and amend sustainability. In this research, we aim to shed light on the possibilities enabled through the emerging additive manufacturing technology in the pursuit of improving the sustainability of the clothing industry.

Additive manufacturing (AM) is a novel production process that is based on the direct manufacturing of a digital model. It is the next step in the development of computer numeric control (CNC) machines, with a single major difference in that it constructs objects in an additive process rather than a subtractive one. This gives AM distinctive characteristics that can radically change the way products are designed, produced, and provided to customers [7]. With AM, items are designed with greater freedom and less manufacturing waste, and can be customized on a case-by-case basis in new business model (NBM) arrangements. If these improvements can be coupled with in situ service provision, then AM can provide an opportunity to redefine sustainability in various industries, including the clothing industry. AM as a production technology may enable maintenance and revitalization of clothing in the use stage of the lifecycle. Moreover, AM potentially can decrease the production of virgin products and consequently reduce the environmental footprint of the clothing and textile industries. However, the obstacles of such implementation should be investigated from different perspectives. This study sheds light on the AM-enabled NBMs in the clothing industry and their potential sustainability impact.

The research questions of this study are as follows:

1. What are the future AM-enabled NBMs for the clothing industry to improve sustainability?

2. What are the opportunities created by NBMs, and what are the existing obstacles to AM utilization in the clothing industry?

The paper is structured in five sections. After the introduction, a literature review of the research subject is presented in Section 2. Section 3 presents the methodology that explains the way we reached the outcomes. Finally, the results of this study are described in Section 4, followed by the conclusions in Section 5 .

\section{Literature Review}

\subsection{Sustainability}

Modern societies, which are dominated by neoliberal capitalism and emphasize the centrality of profit, are exploiting the Earth for resources [8]. This profit-centered approach has raised concerns regarding the future of the environment and societies. Sustainable development (SD) is an approach to introduce a balance among economic, environmental, and societal aspects of human advancements. The World Commission on Environment and Development (WCED) describes SD as "development that meets the needs of the present without compromising the ability of future generations to meet their own needs" [9].

The concepts of sustainability and sustainable development (SD) are studied extensively in the literature for different contexts, and there are various definitions for these terms. For instance, corporate sustainability (CS) refers to "meeting the needs of a firm's direct and indirect stakeholders (such as shareholders, employees, clients, pressure groups, communities, etc.), without compromising its ability to meet the needs of future stakeholders as well" [10]; while corporate social responsibility (CSR) refers to "the obligations of the firm to society or, more specifically, the firm's stakeholders-those affected by corporate policies and practices" [11]. According to Fonseca [12], although there is no consensus on the concept, definition, motivation for application, or potential positive outcomes of sustainability and CSR, most definitions consider an aim for the simultaneous search for successful economic development with social progress and equity and respect for the natural environment to generate value for shareholders, customers, workers, partners, and society in general. Therefore, Strand et al. [13] posit that sustainability can, therefore, be used as an "umbrella construct" that could encompass concepts such as SD, CS, CSR, corporate citizenship (CC), business ethics (BE), and triple bottom line (TBL). 
Some early definitions of sustainability were only focused on the environmental aspect [14-16], while the TBL approach [17,18] also included societal and economic aspects. A holistic view of sustainability adds two more aspects to the TBL approach, which are time and inter-relationship amongst aspects [8]. In their study, Lozano and Huisingh [19] utilized three dimensions of sustainability and four inter-relations between sustainability dimensions to study the sustainability of three companies. The four inter-relationships among sustainability dimensions involved economic and environmental dimensions, social and environmental dimensions, social and economic dimensions, and the interlink between all three dimensions.

Sustainability is considered a current business megatrend with increasing importance due to the globalization of supply chains and an intensified competition for resources among the rising powers such as China and India [20]. Research has shown that there can be a direct relationship between firms' societal impacts and financial results.

Margolis and Walsh [21] reviewed and assessed 109 empirical studies exploring the corporate social performance and financial performance relationship. They realized the existence of a positive association between a company's social performance and its financial performance in about $50 \%$ of the studies, while they only found a negative relationship in about $5 \%$ of the studies [21]. The meta-analysis of 52 studies by Orlitzy et al. [22] also supported the existence of a positive relationship between corporate social/environmental performance and corporate financial performance. Moreover, a considerable number of studies also posited that companies that implement responsible ethical policies and satisfy the expectations of their stakeholders can achieve a higher economic performance than their peers while also creating positive differentiation [23-25].

\subsection{Sustainability in the Clothing and Fashion Industry}

According to the Oxford English Dictionary, fashion is "a popular style of cloth, hair, etc. at a particular time or place; the state of being popular" [26]. The online Encyclopædia Britannica defines the "fashion industry" as a "multibillion-dollar global enterprise devoted to the business of making and selling clothes. Some observers distinguish between the fashion industry (which makes 'high fashion') and the apparel industry (which makes ordinary clothes or 'mass fashion'), but by the 1970s the boundaries between them had blurred" [27]. It continues to describe the components of the fashion industry as " ... the design, manufacturing, distribution, marketing, retailing, advertising, and promotion of all types of apparel (men's, women's, and children's) ... " [27]. The fashion industry "is characterized by short product life cycles, volatile and unpredictable demand, tremendous product variety, long and inflexible supply processes, and a complex supply chain" [28,29]. The textile industry, however, is concerned with the preparation of cloth and fabric through weaving, knitting, bleaching, and dyeing [30].

Merriam-Webster defines garment as "an article of clothing", while defining apparel as "clothing of a particular kind" and defining clothing as "garments in general" [31]. Thus, in this research, clothing, garment and apparel are used indistinctively. According to Stengg [32], the clothing industry is responsible for the transformation of fabrics into products such as garments, textile floor coverings, home textiles, and industrial textiles.

From a supply chain point of view, high in the upstream supply chain, we have the fiber producers using either natural or synthetic materials. The textile mills are the second layer, in which raw fiber is spun, woven, or knitted into fabric. The third layer of the supply chain includes the apparel and industrial textile manufacturers. The fourth and final layer consists of retailers that sell textile products [28].

Therefore, the fashion industry (consisting of high fashion and mass fashion) is the overarching industry that encompasses the clothing industry [33].

The number of studies investigating the various aspects of sustainability in the fashion and clothing industries is increasing partly due to the elevated attention to unsustainable consumption behaviors, and fast-fashion business models. Jia et al. [34], in a systematic literature review, identified four themes including drivers, barriers, practices, and indica- 
tors of sustainable performance when applying a circular economy in the textile industry. Moreover, they determined the relationship between the four themes. In another literature review conducted by Köksal et al. [35], encompassing 45 articles published in English peer-reviewed journals, they assessed the sustainable supply chain management in the textile and apparel industry. Their findings showed that "a company's internal orientation is the main assisting factor in sustainable supply chain management practices". They also concluded that supplier collaboration and assessment can present themselves as a strategy by focal companies to manage social risk [35].

Peters and Simaens [36] explored "a set of institutional, organizational, and individual drivers of and barriers to the integration of sustainability into the corporate strategy of a European textile and clothing company." They identified six drivers of and 10 barriers to sustainability integration in European clothing companies. Their results suggested the need for a strong integration of sustainability measures into the corporate strategy and daily tasks to achieve success in implementation [36]. De Abreu et al. [37] studied the influence of three variables, including the firm size, location, and value chain position, on the adoption of CSR practices by textile firms in Brazil and China. Their findings suggested that the country in which a firm is located strongly influences CSR adoption. Firm size and position in the value chain also exerted significant influences, but to a lesser extent than the country variable [37]. After analyzing 13 common critical success factors of CSR implementation for the Chinese textile industry, Li et al. [38] concluded that "government initiatives" are the most influential common success factor of CSR implementation in Chinese textile industries, while "societal support" is the least influential success factor [38].

Joy et al. [39] investigated the sustainability concerns related to fast fashion, which refers to "low-cost clothing collections that mimic current luxury fashion trends" and the potential role of luxury brands to dissuade consumers from fast fashion. Li et al. [40] examined the effects of CSR on the sustainability performance of companies and their suppliers in a fast-fashion supply chain. They found that from an internal governance perspective, the centrality of the corporation should be strengthened; while from the external governance perspective, "the stakeholders should collaborate to achieve sustainability governance throughout the entire fast fashion supply chain" [40].

Prosumers are becoming an important group with the power to impact the sustainability of the fashion industry [41-44]. Alvin Toffler coined the prosumerism concept as a new phenomenon of the postindustrial age $[45,46]$. In his book The Third Wave, Toffler argued that pure customers will decline in the postindustrial era and be replaced by prosumers [45], who produce many of their own goods and services with immensely enhanced self-help technologies [46]. The prosumers are enabled by the vast availability and affordability of powerful technologies (e.g., internet, 3D printing, design software, etc.) [47]. Other authors defined prosumption as value creation [48] and value exchange [49]. The research on prosumer impact and behavior has been extensive, especially in fields such as smart grids, in which the users of electricity can also sell the electricity produced by their solar panels back to the grid $[50,51]$. The relationship of prosumers in the energy market to sustainability is clear, as they use the renewable energy sources for part of their own needs while selling the rest of the sustainably produced energy to the grid to be used by others [52]. In this research, we refer to the prosumers in the fashion industry who use AM process for their creations.

\subsection{Clothing Lifecycle}

In general, a product lifecycle has five phases as follows: imagine, define, realize, use/support, and retire/dispose. According to Stark [16], in each phase, a product is in a different state. Product lifecycle management (PLM) is an effort to manage each phase effectively to increase product revenue and reduce costs [53].

To study the clothing industry's produced waste, the lifecycle of the products needs to be explored. Steinberger et al. [54] presented a detailed view of the productionconsumption path of a T-shirt. In their illustration, energy, water, and minerals are the 
inputs of the production process; while the outputs, such as gases, consumed water, and discarded clothing impact air, water, and soil. The production steps in a study by Steinberger et al. [54] began with cotton fiber production, which includes farming and ginning, followed by transportation to yarn production through the process of spinning, fabric formation by the knitting process, wet processing for bleaching or dyeing, and T-shirt production through cutting and sewing processes, followed by transportation to the consumption markets. In their illustration, after the retail and use phase, the disposal takes place, which involves incineration, landfills, and water-treatment systems.

In the clothing lifecycle, various production decisions such as the selection of raw materials, quality of clothing confections, and later consumption decisions related to the method of washing and drying are important in the disposal or reusability of the product [6]. Payne [55] illustrated the three possible types of clothing lifecycle management. In the simplest type, the clothing is produced, and after consumption, goes directly to the disposal phase. In the second type, the product is sold/given away for reuse before being sent to the landfill. The first two consumption types follow a cradle-to-grave ideology. However, in the third type, which is the ideal one and illustrates a sustainable lifecycle (cradle to cradle), the product is fully recycled and starts over in the product lifecycle [55].

In another study, Levi Strauss and Co. investigated the total impact of a single pair of Levi's 501 trousers over its lifecycle on the environment. The results showed that $33.4 \mathrm{~kg}$ of $\mathrm{CO}_{2}$ and $48.9 \mathrm{~g}$ of $\mathrm{PO}_{4}$ were released to the environment, while 3781 liters of water was consumed [56].

\subsection{Additive Manufacturing}

Additive manufacturing (AM), also known as three-dimensional printing (3DP), is a method of producing objects directly from a 3D computer-aided design (CAD) file. AM is defined by ISO/ASTM as "the general term for those technologies that based on a geometrical representation creates physical objects by successive addition of material." [57]. A subcategory of direct digital manufacturing (DDM) processes, AM works opposite to conventional production methods, which subtract excess material from a raw shape to achieve the intended geometry. Additive manufacturing produces parts by adding thin cross-sections of the part's three-dimensional geometry, on top of each other, to construct the intended design [58]. These thin two-dimensional cross-sections are produced by the computer software and sent to the AM machine to be laid out of raw material $[59,60]$. This technology, which began in the 1980s as a method of producing prototypes, is currently being adopted for final parts production [61]. The reason for this change can be traced to the unique characteristics of additive manufacturing processes, which are as follows: (a) no need for tooling, which makes customization and design revisions faster and more affordable; (b) feasibility of producing small production batches economically; (c) product optimization for the function is possible, as the design for manufacturability is less restrictive compared to the conventional subtractive processes; (d) the capability to produce complex geometries; (e) potential for simpler supply chains with shorter lead times and lower inventories [62]; and (f) some AM processes allow for reduction of raw material waste.

The limitations of this production method are related to a range of available materials, production finish quality, production rate, production chamber size, repeatability of production, and costs of machines and materials [63].

The body of knowledge also includes several studies that scrutinized the sustainability of additive manufacturing methods from different aspects. Huang et al. [64] identified a number of positive points for different AM processes (stereolithography, selective laser sintering, fused deposition modeling, and laser-engineered net shaping for metals). Their research suggested the emergence of customized healthcare as a societal improvement enabled through AM. They also recognized the health benefits of AM as another societal impact. Research by Chen et al. [65] pointed out the change in consumers' behavior as another impact on the social aspect of sustainability. They explained that the potential 
increased involvement of the consumer in the design and even production that is enabled by the AM can fuel the prosumer (producer-consumer) trends. This can turn out to be positive if the prosumers are aware of the environmental implications of AM, otherwise it can turn out to be negative, with excess waste production [66]. In a positive outcome for all three sustainability aspects, through the improved design and engagement of customers in the design, AM can enable product desirability and consumer attachment, which can lead to lasting consumption [17].

AM has said to be more environmentally friendly than the conventional production methods from the aspect of virgin material and water consumption, as well as waste generation (both in toxic gases and liquid generation, and as a result of on-demand manufacturing reducing the need for inventories and consequently obsolescence) $[64,67,68]$. Ford and Despeisse [69] found that higher machine utilization and pooling of the manufacturing resources are key in the reduction of AM environmental impact.

Economic efficiency also is expected to be achieved through simplification of the supply chain and made-to-order (MTO) concept, while a distributed supply chain can reduce transportation while being near the consumption markets $[63,64,67]$. Atzeni and Salmi [70] suggested the economic savings from AM design, testing, and manufacturing efficiency improvements were even greater than the savings due to toolless production. Ref. [71] studied the direct digital manufacturing promise of savings due to risk reduction in the new product launch process and shortening of the product to market, in addition to the possibility of modifying the product without high costs.

Ford and Despeisse [69] summarized the sustainability improvement areas while using AM, which are product redesign, manufacturing, use, and recycling. Moreover, they discussed the challenges in reaching sustainability improvements and business opportunities. Their research recognized the possibility of NBMs enabled by AM in the field of product lifecycle extension through repair and refurbishment, and remanufacturing and product-service concepts (such as offering a product with an update and upgrade afterward).

\subsection{Business Model}

There are different definitions for a business model in the literature. Amit and Zott [72] described a firm's business model as "a system of interconnected and independent activities that determines the way a company 'does business' with its customers, partners, and vendors" [72]. Baden-Fuller and Morgan [73] explained that a business model's role is "to provide a set of generic level descriptors of how a firm organizes itself to create and distribute value in a profitable manner" [73]. In their monumental publication, Osterwalder et al. [74] defined a business model as a conceptual tool that is comprises "objects, concepts and their relationships with the objective to express the business logic of a firm". They also suggested that a business model allows presenting a simplified description of the value proposition and its financial consequences [74].

The stream of research exploring the NBMs is healthy and vibrant [75-80]. Studies were conducted to better understand the impact of digital transformation on the creation of NBMs [75,80-82], while others investigated the NBMs and their characteristics in different contexts [76-78]. This research intends to contribute to the NBM stream of research.

\subsection{Literature Gap}

The literature review performed in this paper was conducted using academic publication search engines including Google Scholar and Scopus. The Google general search engine was also used to search for news articles and company webpages. The keywords used for the search were: clothing industry sustainability, textile industry sustainability, supply chain sustainability, fashion industry sustainability, additive manufacturing in the clothing industry, additive manufacturing in the apparel industry, additive manufacturing in the garment industry, additive manufacturing in the fashion industry, additive manufacturing in the textile industry, new business models fashion industry, new business models clothing industry, business model innovation, and new business models. The literature 
review began in November 2018 and was concluded in April 2021. The inclusion criteria for the articles were the presence of a case study related to the AM in the fashion industry, the study of sustainability of the AM, and the presentation of new business models enabled by AM.

Although attention towards waste reduction in the clothing industry has increased during recent years [55], and some basic actions have been taken (efforts such as the use of sustainably grown cotton, plant-based polymers, and development of an institute for sustainable consumption to issue labels for products on the basis of carbon emission footprint [6]), there still is work to be done. In recent studies, Baskaran et al. [83] studied the sustainability of clothing suppliers in India. They found several negative environmental and societal impacts, such as pollution and unfair competition amongst manufacturers of garments and child labor employment among manufacturing suppliers. Gardetti and Torres [84] provided an in-depth review of the current clothing industry's sustainability issues. We created Figure 1 to summarize the waste items and the byproducts of the textile and fashion industries presented in different publications $[33,84,85]$.

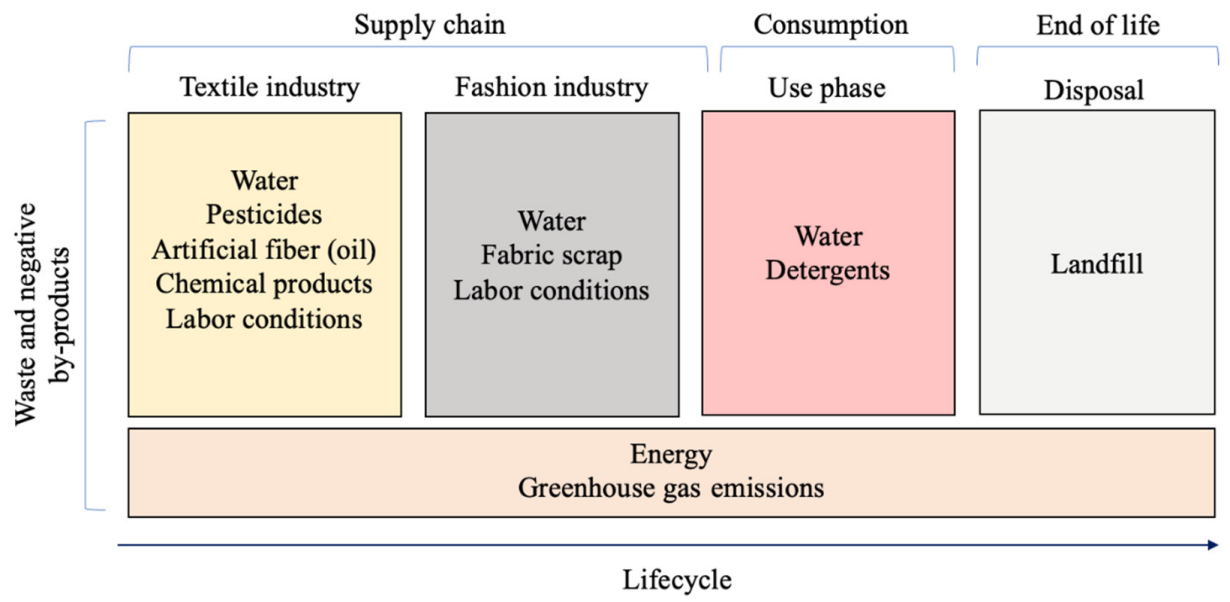

Figure 1. Environmental and social impacts of the textile and fashion industries $[33,84,85]$.

Moreover, studies investigating additive manufacturing suggest that AM is most suitable when the production batch size is small and the product is geometrically complex [62,86]. Petrick and Simpson [87] pointed towards the possibility of an AM-enabled prosumer society; however, research exploring the impact of AM on clothing production practices is lacking. Additive manufacturing has begun to be used by a few fashion designers to produce high-end dresses and clothing pieces; however, to expand our understanding concerning the opportunities raised by these efforts and future possibilities, research is required. In this research, we aim to fill this gap.

\section{Research Method}

The methodology of this research was a conceptual study of the possible AM-enabled NBMs in the clothing industry utilizing sustainability frameworks from the literature [15]. Unlike a theory paper, conceptual studies do not require proposing a new theory, but seek to connect existing frameworks and theories in an interesting way, bridge findings across disciplines, create insights, and expand the scope of our thinking [88,89]. This method was chosen specifically since AM technology is still in the development phase, and only recently have companies such as Airbus, Boeing, GE, Ford, begun industrialgrade applications. However, AM in the garment industry remains very exclusive and has only begun to demonstrate a promising future [90]. Currently, there are no large implementations of AM for the production of clothing items (only for accessories such as shoe soles by Nike, Adidas, and New Balance [91]), and therefore, the NBMs that would emerge when AM goes mainstream are unknown. To conduct this conceptual study, we reviewed the relevant literature on "sustainability frameworks", "clothing industry", 
and "additive manufacturing and AM sustainability" to create the foundation needed to envisage possible AM-enabled NBMs in the clothing industry. We supported our NBMs based on the emerging or existing business models in other industries, as well as AMenabled ones. For this purpose, secondary data from reputable businesses, manufacturing companies, and news articles were also utilized.

Each NBM then was analyzed against a modified sustainability framework used by Lozano and Huisingh [19] in their sustainability case study. The modification was performed using the "AM sustainability" literature. Table 1 presents our modified sustainability framework for AM business models and combines the findings of [19] and adapts it for AM. In our sustainability framework (Table 1), there were three main sustainability dimensions, societal, economic, and environmental, as well as a fourth dimension created from the overlap of these three dimensions. Table 1 also presents the factors involved in each sustainability dimension.

Table 1. A sustainability framework for AM.

\begin{tabular}{ll}
\hline Dimensions and Interlinks & Factors \\
\hline Economic & $\begin{array}{l}\text { The factors mentioned by Lozano and Huisingh [19] } \\
\text { Excluding acquisitions }\end{array}$ \\
\hline Environmental & $\begin{array}{l}\text { The factors mentioned by Lozano and Huisingh [19] } \\
\text { Excluding biodiversity }\end{array}$ \\
\hline Social & The factors mentioned by Lozano and Huisingh [19] \\
\hline $\begin{array}{l}\text { Relations between economic, } \\
\text { environmental, and social aspects }\end{array}$ & Time dimension (prosumerism) \\
\hline
\end{tabular}

\section{Results}

In this section, we present the research findings and discuss the potential benefits and lifecycle-extending possibilities that can be achieved from the introduction of direct digital manufacturing processes such as AM into the clothing industry; then we present the obstacles to this implementation. Finally, AM-enabled NBMs are explained and analyzed for their sustainability.

\subsection{Potential Benefits and Possibilities}

The inception of additive manufacturing as a flexible method of producing various types of parts and products can become a potential method to improve the sustainability of articles of clothing and extend their lifecycles. In industry, the main attraction of additive manufacturing is the capability of producing very complex geometries in very small batches (as small as one). This technology can also be used to produce, repair, and refurbish future clothing without excess transportation in the nearest three-dimensional printing bureaus or at home [63]. Moreover, designs like the one presented in Refs. [92,93] enable modular and reconfigurable shoes and clothing, which in turn makes the products repairable and novel for different occasions.

Innovation enabled by AM is making shape-changing clothes (also known as 4D printing) a reality [94], which for instance can translate to pairs of shoes that can adjust for the best fit while being worn [95].

With direct digital manufacturing (DDM) technologies such as AM, the prospect of producing perpetual clothing is becoming brighter. Concepts such as printing complex geometries with assemblies [92] and recyclable raw material can radically alter the lifecycle of clothes. Moreover, the new designs and simulation tools are making the limitations on production chamber size meaningless, meaning a dress can be 3D printed in a folded state and then unfolded after the production [92,96].

Electroloom, as an early implementation example [97], went out of business due to financial difficulties and slow technical progress in 2016 [98]. Their process enabled the consolidation of textile and final clothing production phases into a single step, and was 
able to reduce the amount of textile waste. The traditional clothes lifecycle has separate phases for the distribution and retail of the clothing that can also be digitalized. Design files can be acquired from various free or paid (such as Thingiverse or Shapeways) digital design libraries and be printed in distributed production locations near the consumers (e.g., 3D hubs or in-store 3D printing at Staples). This opens up the door for new businesses in the area of clothing refurbishment, renewal, and recycling, which could potentially reduce the waste throughout the clothing lifecycle.

Studying the AM literature allowed us to determine a number of generic benefits for the implementation of AM production technology in the fashion industry (Table 2). The benefits included lower raw material waste; a reduction in water consumption and greenhouse gas emissions; a reduction in supply chain complexity; improvement in workers' safety, health, and human capital; and reducing the workforce employed in the textile and clothing industry.

Table 2. The generic benefits of AM implementation in the fashion industry.

\begin{tabular}{|c|c|}
\hline Benefits & Reason \\
\hline Lower raw material waste [99] & $\begin{array}{l}\text { Additive nature of the process allows for less } \\
\text { scrap and recycling of the raw material }\end{array}$ \\
\hline $\begin{array}{l}\text { Less water consumption and greenhouse gas } \\
\text { generation }[64,68,100]\end{array}$ & Consolidation of manufacturing steps [101] \\
\hline Simplified supply chain [102] & Less transportation and inventories [63] \\
\hline $\begin{array}{l}\text { Better health, safety, and human } \\
\text { capital development }\end{array}$ & Reshoring, training, and automation [103] \\
\hline $\begin{array}{l}\text { Reduces the worker employment for textile } \\
\text { and clothing production }\end{array}$ & $\begin{array}{l}\text { Combination of fabric and garment production } \\
\text { and automation of the production process [101] }\end{array}$ \\
\hline
\end{tabular}

Figure 2 summarizes the impact of DDM on the clothing lifecycle. In a DDM-enabled clothing industry, clothing becomes significantly more recyclable, which in turn reduces the amount sent to landfills. Production efficiency increases due to the consolidation of manufacturing steps, which leads to a shorter time to market and potential for production reshoring (reduction of transportation of final goods). Delivery processes are significantly different from current methods, while DDM is widely in use. This means the retail and distribution will be digitalized and be given to the local DDM bureaus. Users can transform into designers with enabling software tools that help them customize their clothing according to their tastes. Moreover, the process of use can be combined with reuse and renewal, in which a customer reconfigures a dress or changes some parts of a pair of shoes.

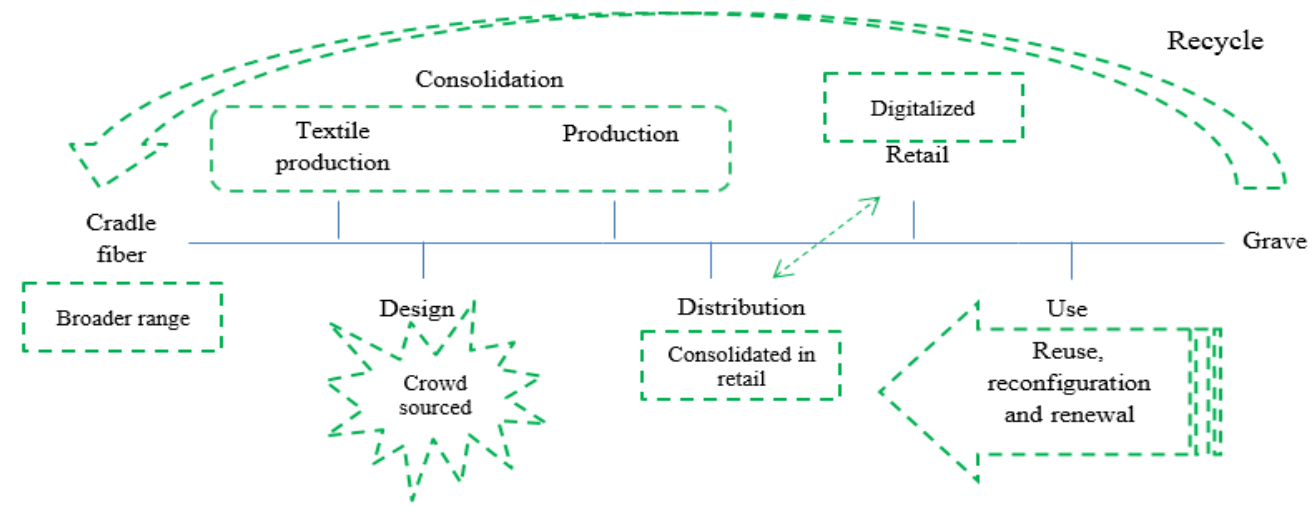

Figure 2. The potential changes posed by direct digital manufacturing to the clothing lifecycle [101,104]. 


\subsection{Current Obstacles to Introduce DDM in the Clothing Industry}

The current obstacles to the implementation of DDM processes in the clothing industry can be categorized into time-dependent and time-independent. The first category, which will be solved through time and technological advancements, includes the following:

- Raw material range limitations [105];

- $\quad$ Cost- and time-intensiveness of the processes [93];

- $\quad$ Accessibility of machines [106,107];

- The maturity of technology (concerning multimaterial processes and automation) [108];

- Clothing brands' support [109].

Time-independent factors, which can be more difficult to unravel, have their roots in consumer behavior and tendencies, and are as follows:

- Design knowledge [110];

- $\quad$ Reluctance to participate in the production process [107];

- $\quad$ Lack of retail store experience when using made-to-order DDM for clothing [111].

\subsection{The Requirements for Introducing DDM-Enabled Perpetual Clothing}

After reviewing the obstacles to perpetual clothing realization enabled by DDM, we now introduce the requirements of such products and our proposed lifecycle diagram for them (Figure 3).

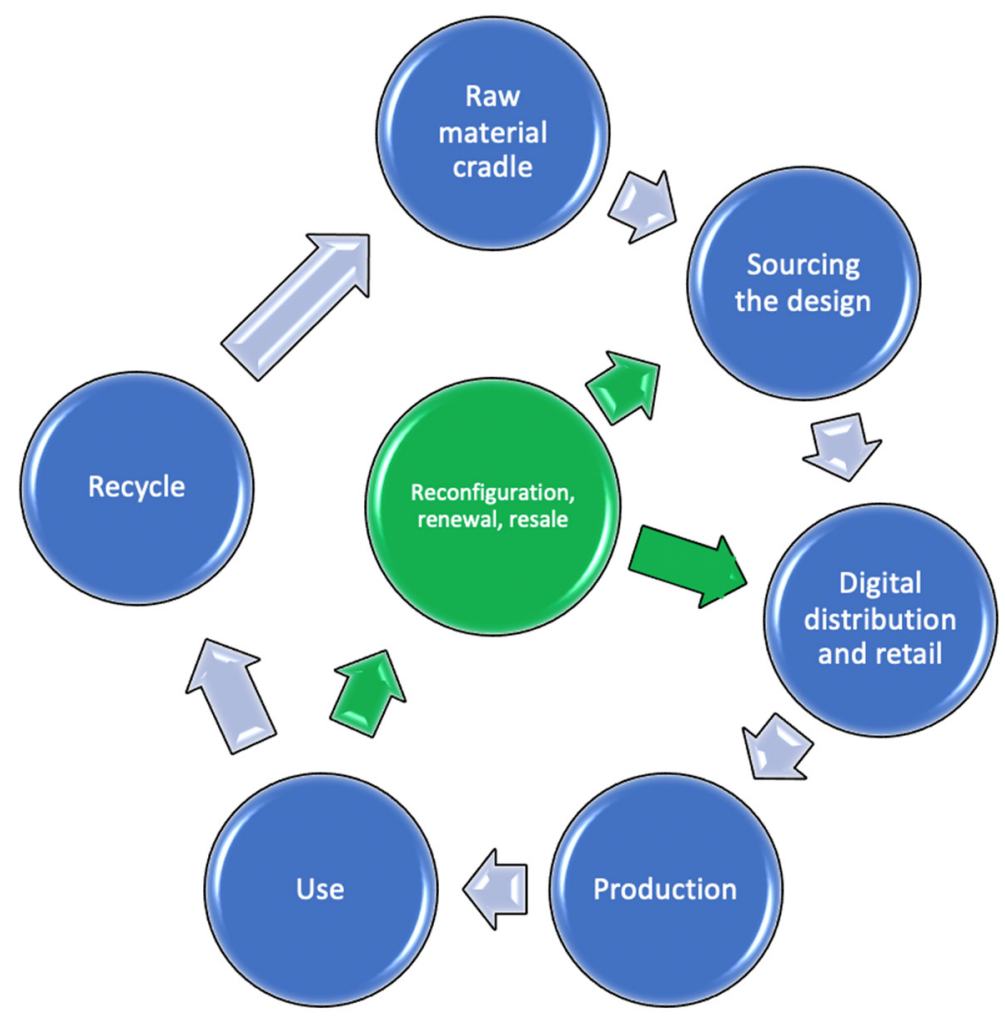

Figure 3. The proposed lifecycle of DDM-created clothing.

The lifecycle begins with the raw material cradle and continues as the clothing design is sourced for DDM, followed by digital distribution for manufacturing and use. When the use phase ends, based on the raw material used for the DDM clothing, it then can be decided either to fully recycle and reuse the raw material for a new design, or to repair and recirculate the items. An important aspect of the DDM-enabled clothing lifecycle is that feedback for improvements can be given to the designers after the renewal.

The establishment of services in this field might be crucial to the development and spread of these products. For instance, to ensure that the products are of the quality 
that is required or to provide a point of contact for the consumers who are not willing to give up on the physical experience of purchasing, the service providers can function as enablers. Moreover, the last phases of DDM-created clothing can be enhanced. In the reuse, reconfiguration, and renewal, the service provider can purchase back the products for refurbishment and resale or recycling.

\subsection{New Business Models}

This section is dedicated to the detailed description of possible future AM-enabled NBMs in the clothing industry, and examination of each model from sustainability perspectives utilizing the framework explained in the methodology.

Three NBMs are detailed through the study of current AM applications in other industries as well as current fashion trends. However, to implement any of the discussed NBMs on a large scale, the obstacles discussed in Section 4.2 need to be addressed first.

\subsubsection{The Clothing as a Service}

Commercialization of additively manufactured clothing can take place in a contractbased quality- and maintenance-assurance setting. Currently, a number of clothing companies are emerging that offer clothing as a service, meaning that with every physical item a customer purchases, a long-term commitment by the seller guarantees the maintenance of the item for an extended period (e.g., 30 years) [112]. This concept shifts the focus of business from fast-fashion product circulation towards aftersales service provision. This is an area in which AM can perform strongly [63]. In this NBM, the profitability of the company is assured through the use of durable material coupled with high-quality production systems. Moreover, this NBM can also provide updates and upgrades to customers as time passes and the product goes out of fashion.

In such a setting, AM machines are located in a distributed configuration near the main consumer communities to facilitate in situ maintenance of the items. All the machines are connected to the company's design database and can produce various sections of the item to be replaced on customers' items as required. Inventory of the fabric and other necessary items (e.g., shoe hills, etc.) will be replaced by raw materials ready to be transformed into required service items. However, consumers have shown in different instances (Zady Company, Nudie Jeans Co., and Hiut Denim) that they are willing to invest more in higher-quality products with supply-chain transparency, however, the implementation of such an NBM in the clothing industry is contingent upon addressing the issues discussed in Section 4.2.

This NBM brings the idea of perpetual clothing closer to a reality in which the use phase of the clothing is lengthened, and the product can be returned to the manufacturer at the end of the production for recycling. This NBM is most suitable for high-fashion products and not as suitable for mass-fashion items.

\section{Sustainability of AM-Enabled Clothing as a Service}

From a purely economic perspective, clothing as a service can provide higher profits to the producer, as the initial investment by the consumer in the product is multiple times of a regular item. The same concept has proved profitable in industrial settings [113]; it enabled the producer to shorten the product to market cycle, as the process of fabric production and making the clothes was combined in a single step. Intellectual property rights (IPR) will not be an issue, as the design and production procedure is not shared with the customer or third-party service providers.

From an environmental perspective, although it depends on the exact AM process and various machines from different manufacturers shown to have distinct environmental footprints [68,100], water and material consumption in AM processes are lower than conventional ones [64]. In the clothing industry, wastewater generation is a problem that AM can address. Moreover, some additive manufacturing processes create less waste and allow for the recycling of excess material [99], therefore supporting the adoption of circular 
economy (CE). Energy consumption by AM cannot be concluded, as the production of AM raw material by itself is energy-intensive, and each process has a different energy requirement. As this NBM lengthens the use phase of the clothing lifecycle, it saves energy for transforming new raw material into new clothing. Additionally, the central management of the items can enable the clothes to be repaired, reconfigured, and recycled. All this contributes to less waste generation in the use phase of the product.

From a societal perspective, AM reduces worker employment for fabric and clothing production through the combination and automation of the production processes [101]. Moreover, lengthening the clothing lifecycle in this NBM shifts jobs from manufacturing towards higher-paying jobs of repair and manufacturing that, if localized, can improve conditions of the workers by "reshoring" jobs [103]. In addition, AM utilization for production requires a designer, machine technicians, and operators, all of whom require training and human capital investment by the company [114]. This is a positive socioeconomic impact of AM implementation.

Moreover, as the production, repair, and upgrade facilities can be placed near the consumption centers through the distributed AM implementation, it reduces the cost of clothing inventory production, storage, and transportation [63]. This change has an impact on all three aspects of sustainability in a positive way. AM can also reduce health issues for the workers and make their jobs safer and less hazardous through automation.

\subsubsection{Collaborative Consumption}

Currently, social trends fueled by social media that discourage women from repeat usage of their outfits during different events has enabled a new wave of companies to emerge. These firms (e.g., "Rent the Runway", "The Black Tux", "Chic by Choice", etc.) have rent-not-buy business models for the in-season luxury brands, and bring the sharing economy to the clothing industry. The use of AM to produce high-end fashion items (e.g., dresses, shoes, accessories) is underway; however, items are costly and difficult to acquire [115]. Moreover, customer uncertainty about fit and comfort makes the purchase of such items risky for mainstream consumers. In the niche, custom-designed luxury items such as the dresses presented in Refs. [92,93,96], a "pay-per-use" or "rental" NBM can reduce the price tag significantly and make the item available to a larger market.

In this NBM, dresses and items are designed by various designers for brands or individual production companies. Additively manufactured items are then delivered to rental locations based on the order. This concept utilizes AM in centralized locations or through licensed third-party AM production service providers to ensure the quality of the products. This NBM will likely be among the first models used for AM-enabled clothing manufacturers because it lowers the cost of ownership significantly while consumers are familiarized with the AM-made clothing. This NBM also is suitable in the beginning only for high-fashion clothing, but as the AM technology improves, can also be implemented by the local companies for higher-end mass-fashion items such as shoes.

\section{Sustainability of the Sharing Business Model for Clothing}

In addition to general benefits gained from AM utilization, this NBM increases clothing utilization, and through that saves water, energy, and materials from utilization in the production of fast-fashion items. It also reduces greenhouse gas generation for the same reason. The clothing can be recycled, remanufactured, or updated by the original equipment manufacturer (OEM) after the end of the season. This NBM can reduce the use of fast-fashion items, which in turn will impact the profitability of those firms negatively.

\subsubsection{Direct Sale or Distribution}

Digital distribution enables the acquisition of clothes design files from the designer or the clothing company to be produced on a home printer or through licensed third-party producers. This concept, which is the AM-enabled version of Dell's famous direct sale business model, may be implemented in for-profit or open-source settings. Currently, this 
business model is in use by companies such as Shapeways and i.materialise, which offer a platform for designers to find customers for their designs before it is printed by those companies. On the other hand, Thingiverse and 3D Warehouse provide an open platform for sharing 3D models that can be printed on any 3D printer a consumer chooses.

This NBM can be implemented with various consumer involvements. From a shoe company that offers various designs for made-to-order to an open-source platform that allows the user to modify the design before producing it on their home 3D printer, there are various degrees of prosumerism. Therefore, AM direct sales or distribution provide a high level of customization and consumer involvement throughout the product inception cycle. This NBM will be most suitable for both high-fashion products and high-end mass-fashion products. For the high-fashion items, a design house would employ a certified digital manufacturing company to ensure the highest quality and predictable reliability to mitigate the risk of damaging the brand reputation from low product quality and unacceptable workmanship. Ultimately, as AM technology improves, this NBM can become very popular for every type of clothing item.

\section{Sustainability of Direct Distribution for Clothing}

This NBM brings prosumerism closer to reality, and replaces one-size-fits-all with mass customization [17]. Customization and personalization of clothing improve product desirability and extend its lifecycle. However, if desktop manufacturing is not coupled with consumer environmental awareness, it can lead to increased production of waste. Moreover, IPR can become a serious issue for the economic sustainability of this NBM in a for-profit setting.

Through prosumerism, the clothing supply chain will radically change. Designs can originate from different sources and be manufactured at home or on a local AM machine. Current fast-fashion brands can be transformed into digital file sellers with lower inventories and local production cells. Such changes can increase clothing consumption even more and accelerate fast fashion. This will put more pressure on resource consumption and waste generation. However, if an improvement in consumers' awareness and use of green and recyclable raw materials become part of this transformation, then the environmental and societal impacts will be less negative.

This NBM may result in even more waste in the clothing industry if not implemented responsibly. However, if implemented consciously to create personalization of clothing items, then this NBM can improve the products' lifecycle and make the industry more sustainable. To improve the sustainability of this NBM, a number of complementary technologies might be required. For instance, the availability of precise virtual fitting can reduce the waste generation from unfit clothing. The development of recyclable materials for clothing can be another necessary technological step.

\section{Conclusions}

Although the clothing industry in its current state is facing sustainability issues concerning the consumption growth (fast- fashion trends and increasing consumption in developing countries), there are limited positive actions (such as the use of sustainably grown cotton, eco-fashion, and regulations to ban specific chemicals in the production of clothing) to prevent the worsening of the situation. However, in this study, we evaluated the possibilities enabled by AM as a novel and emerging technology that has been called the enabler of the third industrial revolution [7]. Additive manufacturing may radically change the way products are manufactured. When the technology is ready to produce the clothing items, many conventional concepts such as one-size-fits-all, build for inventory, and planned obsolescence will be radically changed. Clothing repair, reconfiguration [92], full raw material recycling, and design personalization can become feasible and accessible to everyone $[17,69]$. However, a concern is that the widespread use of AM through desktop manufacturing can facilitate the production of clothing items without closing the raw material recycling loop and elevate the production of waste. In this research, we explored 
the current state of AM technology and its state of implementation in clothes production, and pointed out the obstacles that need to be addressed before its wide utilization for the production of clothing. The limitations concerning machine and material costs, availability of suitable raw materials, automation of the secondary processes, and brand support are time-dependent issues. On the other hand, lack of retail store experience, design knowledge requirements, and enthusiasm to take part in the production process were classified as the time-independent obstacles to AM utilization in the clothing industry.

Three distinct potential AM-enabled NBMs for the future of the clothing industry were recognized and explained. Clothing as a service, collective consumption, and direct distribution are expected to have different levels of sustainability implications in the clothing industry. We utilized a holistic sustainability framework developed by Lozano and Huisingh [19] to assess the opportunities from each NBM. Our findings suggested several generic benefits were shared amongst all NBMs. Lower raw material waste due to the additive nature of the process; lower water consumption and greenhouse gas generation due to the consolidation of manufacturing steps; a simplified supply chain with less transportation and inventories; and better health, safety, and human capital development were pointed out as the generic benefits of AM implementation in the clothing industry.

For clothing as a service NBM, repair, remanufacturing, updating, and upgrading of the clothes in a distributed local service center will lengthen the product lifecycle and improve the environmental, societal, and economic aspects of sustainability for the clothing industry. The collective consumption NBM brings high-end clothing to the masses and increases the reuse and utilization of clothing items, and through that impacts environmental and societal aspects of sustainability. Direct distribution is a digital version of Dell's famous business model. This NBM enables the consumer to participate in the design and production of their clothing; in other words, creating prosumers. This can result in increased desirability (through customization) of each item and make fast fashion less trendy. In another scenario, a direct distribution NBM, if not coupled with increased environmental awareness and green and recyclable raw materials, can increase the waste generation and increase the negative impact of the clothing industry on the environmental aspect of sustainability.

As the AM field of research is further developing and different industries are finding it as a serious source of competitive advantage, we expect it will not be different for the clothing industry. Therefore, we suggest future research in this field to explore the integration of AM as a complementary production method beside conventional processes to improve clothing industry sustainability. Moreover, research on the adoption of Industry 4.0 and digital transformation by the clothing industry would also be worthwhile. Finally, realworld case studies of AM utilization in the clothing industry will be of great scientific value.

Funding: This work was supported by Direct Operations Project under Grant 323831.

Institutional Review Board Statement: Not applicable.

Informed Consent Statement: Not applicable.

Data Availability Statement: Not applicable.

Conflicts of Interest: The authors declare no conflict of interest. The funders had no role in the design of the study; in the collection, analyses, or interpretation of data; in the writing of the manuscript, or in the decision to publish the results.

\section{References}

1. Statista. Global Apparel Market Size Projections from 2012 to 2025, by Region (in Billion U.S. Dollars). 2019. Available online: https:/ / www.statista.com/statistics /279757/apparel-market-size-projections-by-region/ (accessed on 15 June 2019).

2. FashionUnited. Global Fashion Industry Statistics-Inter-National Apparel. Available online: https://fashionunited.com/globalfashion-industry-statistics / (accessed on 15 June 2019).

3. Vaidya, A.K. Globalization: Encyclopedia of Trade, Labor, and Politics; Abc-Clio: Santa Barbara, CA, YSA, 2006 ; Volume 1.

4. Kaye, L. Textile Recycling Innovation Challenges Clothing Industry. 2011. Available online: https://www.theguardian.com/ sustainable-business / textile-recycling-challenges-industry (accessed on 15 June 2019). 
5. Gillson, I.; Poulton, C.; Balcombe, K.; Page, S. Understanding the Impact of Cotton Subsidies on Developing Countries; MPRA: Munich, Germany, 2004.

6. Claudio, L. Waste Couture: Environmental Impact of the Clothing Industry. Environ. Health Perspect. 2007, 115, A449-A454. [CrossRef]

7. Markillie, P. A Third Industrial Revolution. April 2012. Available online: https://www.economist.com/special-report/2012/04/ 21/a-third-industrial-revolution (accessed on 15 June 2019).

8. Lozano, R. Envisioning sustainability three-dimensionally. J. Clean. Prod. 2008, 16, 1838-1846. [CrossRef]

9. WCED (World Commission on Environment and Development). Our Common Future; WCED: Berlin, Germany, 1987.

10. Dyllick, T.; Hockerts, K. Beyond the business case for corporate sustainability. Bus. Strategy Environ. 2002, 11, 130-141. [CrossRef]

11. Smith, N.C. Corporate Social Responsibility: Whether or How? Calif. Manag. Rev. 2003, 45, 52-76. [CrossRef]

12. Fonseca, L. Strategic Drivers for Implementing Sustainability Programs in Portuguese Organizations-Let's Listen to Aristotle: From Triple to Quadruple Bottom Line. Sustain. J. Rec. 2015, 8, 136-142. [CrossRef]

13. Strand, R.; Freeman, R.E.; Hockerts, K. Corporate Social Responsibility and Sustainability in Scandinavia: An Overview. J. Bus. Ethic 2015, 127, 1-15. [CrossRef]

14. Costanza, R. Ecological Economics: The Science and Management of Sustainability; Columbia University Press: New York, NY, USA, 1992.

15. Dobers, P.; Wolff, R. Competing with soft issues-from managing the environment to sustainable business strategies. Bus. Strategy Environ. 2000, 9, 143-150. [CrossRef]

16. Reinhardt, F. Sustainability and the firm. Interfaces 2000, 30, 26-41. [CrossRef]

17. Diegel, O.; Singamneni, S.; Reay, S.; Withell, A. Tools for Sustainable Product Design: Additive Manufacturing. J. Sustain. Dev. 2010, 3, 68. [CrossRef]

18. Slaper, T.F.; Hall, T.J. The triple bottom line: What is it and how does it work. Indiana Bus. Rev. 2011, 86, 4-8.

19. Lozano, R.; Huisingh, D. Inter-linking issues and dimensions in sustainability reporting. J. Clean. Prod. 2011, 19, 99-107. [CrossRef]

20. Lubin, D.A.; Esty, D.C. The sustainability imperative. Harv. Bus. Rev. 2010, 88, 42-50.

21. Margolis, J.D.; Walsh, J.P. Misery Loves Companies: Rethinking Social Initiatives by Business. Adm. Sci. Q. 2003, 48, 268. [CrossRef]

22. Orlitzky, M.; Schmidt, F.L.; Rynes, S.L. Corporate Social and Financial Performance: A Meta-Analysis. Organ. Stud. 2003, 24, 403-441. [CrossRef]

23. Fonseca, L.M.; Ferro, R.L. Does it pay to be social responsible? Portuguese SMEs feedback. Intang. Cap. 2016, 12, 487. [CrossRef]

24. Trudel, R.; Cotte, J. Does Being Ethical Pay? Mit Sloan Manag. Rev. 2009, 50, 61-68.

25. Berrone, P.; Surroca, J.; Tribó, J.A. Corporate Ethical Identity as a Determinant of Firm Performance: A Test of the Mediating Role of Stakeholder Satisfaction. J. Bus. Ethic 2007, 76, 35-53. [CrossRef]

26. Oxford. Fashion. Oxfor Learner's Dictionaries. 2021. Available online: https://www.oxfordlearnersdictionaries.com/definition/ american_english/fashion_1\#: :text=1\%5Buncountable $\% 2 \mathrm{C} \% 20$ countable $\% 5 \mathrm{D} \% 20 \mathrm{a}$,have $\% 20$ come $\% 20$ into $\% 20$ fashion $\% 20$ again (accessed on 15 September 2021).

27. Major, J. Fashion Industry. In Britannica. 2021. Available online: https://www.britannica.com/art/fashion-industry (accessed on 15 September 2021).

28. Şen, A. The US fashion industry: A supply chain review. Int. J. Prod. Econ. 2008, 114, 571-593. [CrossRef]

29. Čiarnienè, R.; Vienažindienè, M. Management of contemporary fashion industry: Characteristics and challenges. Procedia-Soc. Behav. Sci. 2014, 156, 63-68.

30. Babu, B.R.; Parande, A.; Raghu, S.; Kumar, T.P. Textile Technology; Journal of Cotton Science: GA, USA, 2007.

31. Merriam-Webster. Garment. Merriam-Wenster. 2021. Available online: https://www.merriam-webster.com/dictionary/garment (accessed on 15 September 2021).

32. Stengg, W. The Textile and Clothing Industry in the EU; Enterprise Papers: Brussels, Belgium, 2001; Volume 2.

33. Gardetti, M.A.; Torres, A.L. Sustainability in Fashion and Textiles: Values, Design, Production and Consumption; Routledge: New York, NY, USA, 2017.

34. Jia, F.; Yin, S.; Chen, L.; Chen, X. The circular economy in the textile and apparel industry: A systematic literature review. J. Clean. Prod. 2020, 259, 120728. [CrossRef]

35. Köksal, D.; Strähle, J.; Müller, M.; Freise, M. Social Sustainable Supply Chain Management in the Textile and Apparel Industry-A Literature Review. Sustainability 2017, 9, 100. [CrossRef]

36. Peters, J.; Simaens, A. Integrating Sustainability into Corporate Strategy: A Case Study of the Textile and Clothing Industry. Sustainability 2020, 12, 6125. [CrossRef]

37. de Abreu, M.C.S.; de Castro, F.; de Assis Soares, F.; da Silva Filho, J.C.L. A comparative understanding of corporate social responsibility of textile firms in Brazil and China. J. Clean. Prod. 2012, 20, 119-126. [CrossRef]

38. Li, Y.; Pinto, M.C.B.; Diabat, A. Analyzing the critical success factor of CSR for the Chinese textile industry. J. Clean. Prod. 2020, 260, 120878. [CrossRef]

39. Joy, A.; Sherry, J.F., Jr.; Venkatesh, A.; Wang, J.; Chan, R. Fast fashion, sustainability, and the ethical appeal of luxury brands. Fash. Theory 2012, 16, 273-295. [CrossRef]

40. Li, Y.; Zhao, X.; Shi, D.; Li, X. Governance of sustainable supply chains in the fast fashion industry. Eur. Manag. J. 2014, 32, 823-836. [CrossRef] 
41. Perera, C.R.; Hewege, C.R.; Mai, C.V.C. Theorising the emerging green prosumer culture and profiling green prosumers in the green commodities market. J. Consum. Behav. 2020, 19, 295-313. [CrossRef]

42. Lee, Y. Transformation of the Innovative and Sustainable Supply Chain with Upcoming Real-Time Fashion Systems. Sustainability 2021, 13, 1081. [CrossRef]

43. Jessen-Hannula, J. The Urban Prosumer in Finland-A Path to Sustainability; NOVIA: Tammisaari, Finland, 2019.

44. Perera, C.R.; Hewege, C.R. Evolving Prosumer Identity. In Social and Sustainability Marketing; Routledge: Boca Raton, FL, USA, 2021; pp. 175-198.

45. Kotler, P. The Prosumer Movement. In Prosumer Revisited; Springer Science and Business Media LLC: New York, NY, USA, 2010; pp. 51-60.

46. Toffler, A.; Alvin, T. The Third Wave; Bantam Books: New York, NY, USA, 1980; Volume 484.

47. Botelho, D.; Dias, B.; de Oliveira, L.; Soares, T.; Rezende, I.; Sousa, T. Innovative business models as drivers for prosumers integration-Enablers and barriers. Renew. Sustain. Energy Rev. 2021, 144, 111057. [CrossRef]

48. Vargo, S.L.; Lusch, R.F. Evolving to a New Dominant Logic for Marketing. J. Mark. 2004, 68, 1-17. [CrossRef]

49. Humphreys, A.; Grayson, K. The Intersecting Roles of Consumer and Producer: A Critical Perspective on Co-production, Co-creation and Prosumption. Sociol. Compass 2008, 2, 963-980. [CrossRef]

50. Gram-Hanssen, K.; Hansen, A.R.; Mechlenborg, M. Danish PV Prosumers' Time-Shifting of Energy-Consuming Everyday Practices. Sustainability 2020, 12, 4121. [CrossRef]

51. Gautier, A.; Jacqmin, J.; Poudou, J.-C. The prosumers and the grid. J. Regul. Econ. 2018, 53, 100-126. [CrossRef]

52. Kotilainen, K. Energy Prosumers' Role in the Sustainable Energy System; Springer Nature: Cham, Switzerland, 2020.

53. Stark, J. Product Lifecycle Management (Volume 1). In Advances in Through-Life Engineering Services; Springer: Singapore, 2020; Volume 1, pp. 1-29.

54. Steinberger, J.K.; Friot, D.; Jolliet, O.; Erkman, S. A spatially explicit life cycle inventory of the global textile chain. Int. J. Life Cycle Assess. 2009, 14, 443-455. [CrossRef]

55. Payne, A. The Life-cycle of the Fashion Garment and the Role of Australian Mass Market Designers. Int. J. Environ. Cult. Econ. Soc. Sustain. Annu. Rev. 2011, 7, 237-246. [CrossRef]

56. Straussco, L. The Life Cycle of a Jean, Understanding the Environmental Impact of a Pair of Levis 501 Jeans. 2013. Available online: http:/ / levistrauss.com/wp-content/uploads/2015/03/Full-LCA-Results-Deck-FINAL.pdf (accessed on 15 June 2019).

57. ASTM International. ISO/ASTM 52900: 2015-Additive Manufacturing—General Principles—Terminology; ISO/ASTM: West Conshohocken, PA, USA, 2015.

58. Hernandez Korner, M.E.; Lambán, M.P.; Albajez, J.A.; Santolaria, J.; Ng Corrales, L.D.C.; Royo, J. Systematic Literature Review: Integration of Additive Manufacturing and Industry 4.0. Metals 2020, 10, 1061. [CrossRef]

59. Gibson, I.; Rosen, D.W.; Stucker, B.; Khorasani, M. Additive Manufacturing Technologies; Springer: Cham, Switzerland, 2021 ; Volume 17.

60. Hopkinson, N.; Hague, R.; Dickens, P. Rapid manufacturing. In An Industrial Revolution for the Digital Age; John Wiley and Sons Ltd.: Chichister, UK, 2006.

61. Wohlers, T.; Caffrey, T. Wohlers Report 2012: Additive Manufacturing and 3d Printing State of the Industry; Wohlers Associates Inc.: Fort Collins, CO, USA, 2012.

62. Holmström, J.; Partanen, J.; Tuomi, J.; Walter, M. Rapid manufacturing in the spare parts supply chain: Alternative approaches to capacity deployment. J. Manuf. Technol. Manag. 2010, 21, 687-697. [CrossRef]

63. Khajavi, S.H.; Partanen, J.; Holmström, J. Additive manufacturing in the spare parts supply chain. Comput. Ind. 2014, 65, 50-63. [CrossRef]

64. Huang, S.H.; Liu, P.; Mokasdar, A.; Hou, L. Additive manufacturing and its societal impact: A literature review. Int. J. Adv. Manuf. Technol. 2013, 67, 1191-1203. [CrossRef]

65. Chen, D.; Heyer, S.; Ibbotson, S.; Salonitis, K.; Steingrímsson, J.G.; Thiede, S. Direct digital manufacturing: Definition, evolution, and sustainability implications. J. Clean. Prod. 2015, 107, 615-625. [CrossRef]

66. Kohtala, C.; Hyysalo, S. Anticipated environmental sustainability of personal fabrication. J. Clean. Prod. 2015, 99, 333-344. [CrossRef]

67. Reeves, P. Additive Manufacturing-A Supply Chain Wide Response to Economic Uncertainty and Environmental Sustainability; Econolyst Limited: Derbyshire, UK, 2009.

68. Sreenivasan, R.; Goel, A.; Bourell, D. Sustainability issues in laser-based additive manufacturing. Phys. Procedia 2010, 5, 81-90. [CrossRef]

69. Ford, S.; Despeisse, M. Additive manufacturing and sustainability: An exploratory study of the advantages and challenges. J. Clean. Prod. 2016, 137, 1573-1587. [CrossRef]

70. Atzeni, E.; Salmi, A. Economics of additive manufacturing for end-usable metal parts. Int. J. Adv. Manuf. Technol. 2012, 62, 1147-1155. [CrossRef]

71. Khajavi, S.H.; Partanen, J.; Holmström, J.; Tuomi, J. Risk reduction in new product launch: A hybrid approach combining direct digital and tool-based manufacturing. Comput. Ind. 2015, 74, 29-42. [CrossRef]

72. Amit, R.; Zott, C. Creating Value through Business Model Innovation; MIT Sloan: Cambridge, MA, USA, 2012.

73. Baden-Fuller, C.; Morgan, M.S. Business Models as Models. Long Range Plan. 2010, 43, 156-171. [CrossRef] 
74. Osterwalder, A.; Pigneur, Y.; Tucci, C.L. Clarifying business models: Origins, present, and future of the concept. Commun. Assoc. Inf. Syst. 2005, 16, 1. [CrossRef]

75. Berman, S.J. Digital transformation: Opportunities to create new business models. Strat. Leadersh. 2012, 40, 16-24. [CrossRef]

76. Michelini, L.; Fiorentino, D. New business models for creating shared value. Soc. Responsib. J. 2012, 8, 561-577. [CrossRef]

77. Seelos, C.; Mair, J. Social entrepreneurship: Creating new business models to serve the poor. Bus. Horiz. 2005, 48, 241-246. [CrossRef]

78. Kley, F.; Lerch, C.; Dallinger, D. New business models for electric cars-A holistic approach. Energy Policy 2011, 39, 3392-3403. [CrossRef]

79. Dahan, N.M.; Doh, J.P.; Oetzel, J.; Yaziji, M. Corporate-NGO Collaboration: Co-creating New Business Models for Developing Markets. Long Range Plan. 2010, 43, 326-342. [CrossRef]

80. Bélissent, J. Getting Clever about Smart Cities: New Opportunities Require New Business Models; Forrester: Cambridge, MA, USA, 2010; Volume 193, pp. 244-277.

81. Zimmerman, H.D. Understanding the Digital Economy: Challengers for New Business Models. In Proceedings of the AMCIS Proceedings, Long Beach, CA, USA, 10-13 August 2000.

82. Remane, G.; Hanelt, A.; Nickerson, R.C.; Kolbe, L.M. Discovering digital business models in traditional industries. J. Bus. Strat. 2017, 38, 41-51. [CrossRef]

83. Baskaran, V.; Nachiappan, S.; Rahman, S. Indian textile suppliers' sustainability evaluation using the grey approach. Int. J. Prod. Econ. 2012, 135, 647-658. [CrossRef]

84. Goworek, H. Social and environmental sustainability in the clothing industry: A case study of a fair trade retailer. Soc. Responsib. J. 2011, 7, 74-86. [CrossRef]

85. Beall, A. Why Clothes Are So Hard to Recycle? BBC Online, 2020. Available online: https://www.bbc.com/future/article/20200710 -why-clothes-are-so-hard-to-recycle (accessed on 15 September 2021).

86. Tuck, C.J.; Hague, R.J.M.; Ruffo, M.; Ransley, M.; Adams, P. Rapid manufacturing facilitated customization. Int. J. Comput. Integr. Manuf. 2008, 21, 245-258. [CrossRef]

87. Petrick, I.J.; Simpson, T.W. 3D Printing Disrupts Manufacturing: How Economies of One Create New Rules of Competition. Res. Manag. 2013, 56, 12-16. [CrossRef]

88. Cropanzano, R. Writing Nonempirical Articles for Journal of Management: General Thoughts and Suggestions. J. Manag. 2009, 35, 1304-1311. [CrossRef]

89. Gilson, L.L.; Goldberg, C.B. Editors' Comment: So, What Is a Conceptual Paper? Journal of Group and Organization Management: New York, NY, USA, 2005.

90. Sitotaw, D.B.; Ahrendt, D.; Kyosev, Y.; Kabish, A.K. Additive Manufacturing and Textiles—State-of-the-Art. Appl. Sci. 2020, 10, 5033. [CrossRef]

91. Beiderbeck, D.; Krüger, H.; Minshall, T. The Future of Additive Manufacturing in Sports. In Predictive Intelligence for Data-Driven Managers; Springer Science and Business Media LLC: Berlin, Germany, 2020; pp. 111-132.

92. Jessica. Kinematic Petals Dress Debuts at MFA. 2016. Available online: http:/ /n-e-r-v-o-u-s.com/blog/?p=7162 (accessed on 15 June 2019).

93. Brownlee, J. You Can Customize and Buy This 3d Printed Dress Online. 2016. Available online: https://www.fastcompany.com/ 3058246/you-can-customize-and-buy-this-3-d-printed-dress-online (accessed on 15 June 2019).

94. Campbell, T.A.; Tibbits, B.; Garrett, B. The Next Wave: 4D Printing Programming the Material World; Atlantic Council: Washington, DC, USA, 2014.

95. Bain, M. Mits Experimental 3d-Printed Sneaker Shape-Shifts to Fit Your Foot. 2015. Available online: https://qz.com/541209 / mits-experimental-3d-printed-sneaker-shape-shifts-to-fit-your-foot/ (accessed on 15 June 2019).

96. Jessica. Moma Acquires First Kinematics Dress. 2014. Available online: https://n-e-r-v-o-u-s.com/blog/?p=6280 (accessed on 15 June 2019).

97. Hipolite, W. The Electro Loom Becomes the World's First 3d Printer of Fabric Launches on Kickstarter. 2015. Available online: http:/ /3dprint.com/65959/electroloom-3d-fabric-printer/ (accessed on 15 June 2019).

98. Rowley, A. Thanks and Farewell. 2016. Available online: https://medium.com/electroloom-blog/thanks-and-farewell-b0c128c3 $043 f$ (accessed on 15 June 2019).

99. Sanchez, F.A.C.; Boudaoud, H.; Camargo, M.; Pearce, J.M. Plastic recycling in additive manufacturing: A systematic literature review and opportunities for the circular economy. J. Clean. Prod. 2020, 264, 121602. [CrossRef]

100. Le Bourhis, F.; Kerbrat, O.; Hascoet, J.-Y.; Mognol, P. Sustainable manufacturing: Evaluation and modeling of environmental impacts in additive manufacturing. Int. J. Adv. Manuf. Technol. 2013, 69, 1927-1939. [CrossRef]

101. Khajavi, S.H.; Holmström, J.; Baumers, M. Additive manufacturing as a platform for introducing cyber-physical services. In Proceedings of the 3rd International Conference on Progress in Additive Manufacturing (Pro-AM), Singapore, 14-17 May 2018.

102. Khajavi, S.H.; Ituarte, I.F.; Jaribion, A.; An, J.; Kai, C.C.; Holmstrom, J. Impact of Additive Manufacturing on Supply Chain Complexity. In Proceedings of the 53rd Hawaii International Conference on System Sciences, Maui, HI, USA, 7-10 January 2020.

103. Fratocchi, L. Additive manufacturing technologies as a reshoring enabler: A why, where and how approach. World Rev. Intermodal Transp. Res. 2018, 7, 264. [CrossRef] 
104. Holmström, J.; Holweg, M.; Lawson, B.; Pil, F.K.; Wagner, S.M. The digitalization of operations and supply chain management: Theoretical and methodological implications. J. Oper. Manag. 2019, 65, 728-734. [CrossRef]

105. Tarmy, J. The Future of Fashion is 3d Printing Cloths at Home. 2016. Available online: https://www.bloomberg.com/news/ articles / 2016-04-15/3d-printing-is-poised-to-bring-haute-couture-into-the-home (accessed on 15 September 2016).

106. Lemu, H.G. On Opportunities and Limitations of Additive Manufacturing Technology for Industry 4.0 Era. In Lecture Notes in Electrical Engineering; Springer Science and Business Media LLC: Berlin, Germany, 2019; pp. 106-113.

107. Halassi, S.; Semeijn, J.; Kiratli, N. From consumer to prosumer: A supply chain revolution in 3D printing. Int. J. Phys. Distrib. Logist. Manag. 2019, 49, 200-216. [CrossRef]

108. Singh, R.; Kumar, R.; Farina, I.; Colangelo, F.; Feo, L.; Fraternali, F. Multi-Material Additive Manufacturing of Sustainable Innovative Materials and Structures. Polymers 2019, 11, 62. [CrossRef]

109. Spahiu, T.; Canaj, E.; Shehi, E. 3D printing for clothing production. J. Eng. Fibers Fabr. 2020, 15, 1-8. [CrossRef]

110. Khajavi, S.H.; Salmi, M.; Holmström, J. Additive Manufacturing as an Enabler of Digital Spare Parts. In Managing 3D Printing; Springer Science and Business Media LLC: Berlin, Germany, 2020; pp. 45-60.

111. Kumar, I.; Garg, R.; Rahman, Z. Influence of retail atmospherics on customer value in an emerging market condition. Great Lakes Her. 2010, 4, 1-13.

112. Ellwood, M. The Only Sweat Shirt You'll Ever Own. 2016. Available online: http://www.bloomberg.com/news/articles/2016-0 7-07/the-only-sweatshirt-you-11-ever-own (accessed on 15 June 2019).

113. Tukker, A. Eight types of product-service system: Eight ways to sustainability? Experiences from SusProNet. Bus. Strat. Environ. 2004, 13, 246-260. [CrossRef]

114. Eyers, D.; Potter, A. Industrial Additive Manufacturing: A manufacturing systems perspective. Comput. Ind. 2017, 92-93, 208-218. [CrossRef]

115. Baggaley, K. Soon You May Be Able to 3d Print Clothing in Your Own Home. 2018. Available online: https:/ /www.nbcnews. $\mathrm{com} / \mathrm{mach} /$ science/soon-you-may-be-able-3d-print-clothing-your-own-ncna848646 (accessed on 15 June 2019). 